\title{
NAPIER'S DESCRIPTIO AND CONSTRUCTIO.
}

John Napier and the Invention of Logarithms, 1614. A lecture by E. W. Hobson. Cambridge, University Press, 1914. $48 \mathrm{pp}$. Cloth, price 1s. $6 \mathrm{~d}$.

Napier and the Invention of Logarithms. By G. A. Gibson. Glasgow, 1914.* 24 pp. Paper.

Some reference has been already made in this Bulletin $\dagger$ to the celebration in 1914, under the auspices of the Royal Society of Edinburgh, of the tercentenary of one of the greatest events in the history of science, namely the publication of John Napier's Mirifici Logarithmorum Canonis Descriptio. According to Professor Hobson this work "embodies one of the very greatest scientific discoveries that the world has seen." J. W. L. Glaisher's judgment, which seems to be also that of Professor Gibson (page 13), is, that " with the exception of the Principia of Newton, there is no mathematical work published in the country which has produced such important consequences, or to which so much interest attaches as to Napier's Descriptio." $\ddagger$

Nor was marked enthusiasm with regard to this work lacking among Napier's contemporaries of eminence. This was especially true of Kepler and Henry Briggs (1556-1630), professor of mathematics in London. In his Ephemeris for 1620 Kepler published as the dedication a letter addressed to Napier, congratulating him warmly on his invention and on the benefit he had conferred upon astronomy. Kepler explains how he verified the canon and found no essential errors in it, beyond a few inaccuracies near the beginning of the quadrant. The letter was written July 28, 1619, about two years after Napier's death, of which Kepler had not heard.

And as to Briggs, he wrote thus to Archbishop Ussher in the year 1615:§ "Napper, lord of Markinston, hath set my

* This pamphlet is a reprint, with separate title-page, of an article in the Proceedings of the Royal Philosophical Society in Glasgow. This article is also reprinted in the very interesting and useful volume: Modern Instruments and Methods of Calculation. A Handbook of the Napier Tercentenary Exhibition, edited by E. M. Horsburgh, London [1914], pp. 1-16. For a review of this work by Professor D. E. Smith, see Science, n. s., vol. 42 , July 23 , 1915, pp. 128-129.

† Vol. 21, Dec., 1914, pp. 123-127.

$\ddagger$ Article "Logarithms" in Encyclopædia Britannica, 11th edition, 1911. \& Ussher's Letters, 1686, p. 36. 
head and hands at work with his new and admireable Logarithms. I hope to see him this summer, if it please God, for I never saw a book which pleased me better and made me more wonder."* Again, Thomas Smith in his Life of Briggs $\dagger$ says of him (Gibson, page 16) when describing his enthusiasm over the Canon Mirificus: "He cherished it as the apple of his eye; it was ever in his bosom or in his hand, or pressed to his heart, and, with greedy eyes and mind absorbed, he read it again and again.... It was the theme of his praise in familiar conversation with his friends, and he expounded it to his students in the lecture room."

Briggs paid his anticipated visit to Napier in the summer of 1615 , and William Lilly, the astrologer, has told usł of his reception at Merchiston: "I will acquaint you with one memorable story, related unto me by John Marr, an excellent mathematician and geometrician, whom I conceive you remember. He was servant to King James I and Charles I. When Merchiston first published his Logarithms Mr. Briggs,

* Sir John Leslie (1766-1832), for many years professor of mathematics and physics in Edinburgh University, was less restrained in his admiration, and characterizes the invention of logarithms as "the noblest conquest ever achieved by man" (Philosophy of Arithmetic, Edinburgh, 1817, p. 156). In a few copies of the English edition of the Constructio published at London in 1616, a cancelled leaf with eulogistic Spencerian verses by one Thomas Bretnor, has not been cut out. These verses begin:

Pull off your laurel rayes, you learned Greekes Let Archimed and Euclid both give way,

and the final stanzas are:

And bonnets vaile; you Germans! Rheticus, Reignoldus, Oswald and John Regiomont, Lansbergius, Finckius and Copernicus,

And thou Pitiscus, from whose clearer font We sucked have the sweet from Hellespont.

For were your labours ne'er composed so well Great Napier's worth they could not parallel.

By thee great Lord we solve a tedious toyle, In resolution of our trinall lines, We need not now to carke, to care, or moile, Sith from thy witty braine such splendour shines, As dazels much the eyes of deepe divines.

Great the invention, greater is the praise, Which thou unto thy nation hence dost raise." 1707

† Vitae quorundam eruditissimorum et illustrium virorum. Londini, $\ddagger$ Lilly’s Life, London, 1721. 
then reader of the astronomy lectures at Gresham College in London, was so surprised with admiration of them that he could have no quietness in himself until he had seen that noble person whose only invention they were. He acquaints John Marr therewith, who went into Scotland before Mr. Briggs, purposely to be there when these two so learned persons should meet. Mr. Briggs appoints a certain day when to meet at Edinburgh; but, failing thereof, Merchiston was fearful he would not come. It happened one day as John Marr and the Lord Napier were speaking of Mr. Briggs, 'Oh! John,' saith Merchiston, 'Mr. Briggs will not come now'; at the very instant one knocks at the gate, John Marr hastened down and it proved to be Mr. Briggs to his great contentment. He brings Mr. Briggs into my Lord's chamber, where almost one quarter of an hour was spent, each beholding other with admiration, before one word was spoken. At last Mr. Briggs began,- ' My Lord, I have undertaken this long journey purposely to see your person, and to know by what engine of wit or ingenuity you came first to think of this most excellent help unto astronomy, viz. the Logarithms; but, my Lord, being by you found out, I wonder nobody else found it out before, when now being known it appears so easy."

Napier and Briggs must have been kindred spirits, for Briggs spent a month at Merchiston, and returned the following summer. He had also planned another visit in the summer of 1617, but Napier's death intervened.

The Descriptio is a small quarto containing an ornamental title page, ${ }^{*}$ preface, 57 pages of explanatory matter, and 90 pages of tables, one page of which is reproduced by Hobson. The preface contains Napier's own account of his invention: "Seeing there is nothing (right well-beloved students of the Mathematics) that is so troublesome to mathematical practice; nor that doth more molest and hinder calculators, than the multiplications, divisions, square and cubical extractions of great numbers, which besides the tedious expense of time are for the most part subject to many slippery errors, I began therefore to consider in my mind by what certain and ready art I might remove those hindrances. And having thought

* A facsimile is given in Mark Napier's Memoirs of John Napier of Merchiston, his lineage, life and times, with a history of the invention of logarithms. London, 1834, p. 374. 
upon many things to this purpose, I found at length some excellent brief rules to be treated of (perhaps) hereafter. But amongst all, none more profitable than this which together with the hard and tedious multiplications, divisions and extractions of roots, doth also cast away from the work itself even the very numbers themselves that are to be multiplied, divided and resolved into roots, and putteth other numbers in their place which perform as much as they can do, only by addition and subtraction, division by two or division by three."

The explanatory matter contains " an account of Napier's conception of a logarithm, of the principal properties of logarithms and also of their application in the solution of plane and spherical triangles." Napier's well-known rules of circular parts* containing the complete system of formulas for the solution of right-angled spherical triangles are here given. The tables include the logarithms of the sines of angles from $0^{\circ}$ to $90^{\circ}$ at intervals of one minute, to seven or eight places of decimals. The arrangement is semiquadrantal, so that the " differentiæ" which are the differences of logarithms in the same line, are the logarithms of the tangents. It should be borne in mind that, "at that time and long afterwards, the sine of an angle was not regarded, as at present, as a ratio but as a length of that semi-chord of a circle of given radius which subtends the angle at the centre. Napier took the radius to consist of $10^{7}$ units, and thus the sine of $90^{\circ}$, called the whole sine, is $10^{7}$; the sines of smaller angles decreasing to zero. The table is therefore one of the logarithms of numbers between $10^{7}$ and 0 , not for equidistant numbers, but for the numbers corresponding to equidistant angles." Napier's logarithms are not the logarithms now termed Napierian or hyperbolic, that is to say, logarithms to the base $e$ where $e=2.718 \ldots$; the relation between $N$ (a sine) and $L$ its logarithm, as defined in the Descriptio, being $N=10^{7} e^{-L / 10^{7}}$, so that (ignoring the factors $10^{7}$, the effect of which is to render sines and logarithms integral to seven figures), the base is $1 / e$. If $l$ (says Glaisher, l. c.) denotes the logarithm to the base $e$ (that is, the so-called "Napierian" or hyperbolic logarithm) and $L$ denotes, as above, Napier's logarithm, the connection between $l$ and $L$ is expressed by

* Cf. I. Todhunter's Spherical Trigonometry revised by Leathem, London, 1901, p. $51 \mathrm{ff}$. for a discussion of Napier's proof. Reference may also be given to a note by E. O. Lovett in this Bulletin, vol. 4, July, 1898, pp. 552-554. 


$$
L=10^{7} \log _{e} 10^{7}-10^{7} l, \quad \text { or } e^{l}=10^{7} e^{-\mathrm{L} / 10^{7}} .
$$

In an "admonitio" on the last page Napier states that he will publish the mode of construction of the canon in the Descriptio "si huius inventi usum eruditio gratum fore intellexero." Napier did not live to keep this promise. The proposed work had been written however and was published by his son, Robert Napier (assisted by Henry Briggs), in 1619, under the title: Mirifici logarithmorum canonis constructio. It consists of two pages of preface and 67 pages of text. In the text we find a full account of the method of construction of the canon. There is also here, expressed in words, one of the four formulas for the solution of spherical triangles, known as Napier's analogies; the other three, easily deduced from Napier's result, were formulated by Briggs in the appendix. In the Constructio logarithms are called "artificial numbers" (numeri arteficiales) and Robert Napier states that the work was composed several years before Napier had invented the name logarithm.* The Constructio may therefore have been written many years before the publication of the Descriptio in 1614 .

The decimal point in arithmetic appears to have been independently invented by Napier. Decimal fractions were first introduced by Stevin in a tract entitled De Thiende and published in 1585; but his notation is excessively cumbrous. Stevin would have written $652(0) 1(1) 3(2) 7(3) \dagger$ or 652137 , instead of Napier's notation $652 \cdot 137$. It was not till much later, however, that the equivalent of Napier's notation was generally used.

* This term is derived from two Greek words meaning "the number of the ratios." For explanation of the appropriateness of the term consult H. S. Carslaw's paper "The discovery of logarithms by Napier," Math. Gazette, vol. 8, p. 82. (The whole paper is given pp. 76-84;115-119, May, July, 1915. Another paper with the same title was published by Professor Carslaw in Jour. and Proc. Roy. Soc. New South Wales, vol. 48, 1914, pp. 42-72.)

It did not take long for the word logarithm to come into English literature. In Act I, scene 1 of Ben Jonson's comedy, "The Magnetic Lady," which was performed in 1632 and first published in 1640, the following lines occur:

$$
\begin{aligned}
& \text { "Sir Interest } \text { will tell you instantly, by Logarythmes, } \\
& \text { The utmost profit of a stock imployed;" }
\end{aligned}
$$

$\dagger$ A facsimile of a page with this notation from the French edition of Stevin's work is given by D. E. Smith in "History of Decimal Fractions," Teachers College Bulletin, (1), no. 5 (March 12, 1910). 
There have been several different editions of the Descriptio and Constructio. Of the former in Latin, there were issues in $1614,1619,1620,1658,1807, * 1857$ and 1899; there were English editions in 1616, 1618, 1857. The Latin editions of the latter were in 1619, 1620, 1658 and $1899 ; \dagger$ an English edition published by W. R. Macdonald $\ddagger$ at Edinburgh in 1889 is a scholarly work and contains a professedly complete catalogue of various editions of Napier's works. The bibliophile may find titles supplementary to this catalogue in Quaritch's catalogue no. 336 (March, 1915); good copies of the first English or Latin editions of the Descriptio and of the first Latin edition of the Constructio are worth about $\$ 100$ apiece.

It is not within the scope of the title which I have chosen for this paper to do more than point out that: (1) it was wholly independent of suggestion from any one else that Napier recognized the advantages, and indicated means for calculation, of a system of logarithms in which $\log 1=0$ and $\log$ $10=10^{10}$. "This is practically equivalent to the assumption $\log 10=1$, as the former assumption merely indicates that the logarithms are to be calculated to 10 places of decimals." (2) The system of logarithms invented by Joost Bürgi (1552-1632), a Swiss watchmaker and instrument-maker, is decidedly inferior to that of Napier, "and the knowledge of the use of logarithms which was spread in the scientific world was entirely due to Napier."

Both of the sketches under review are remarkably interesting and should be in every mathematical library. Professor Hobson develops, at some length, Napier's methods in connection with his tables. $\$$ This is only briefly touched upon by Professor Gibson who sets forth, in his wonted attractive style, the main facts of Napier's life, dwelling especially upon his intimate relations with Briggs. This latter sketch is the longer although it contains the smaller number of pages.

BRown UNIVERSITY,

R. C. Archibald. Providence, R. I.

* F. Maseres, Scriptores logarithmici. London, vol. 6, 1807.

$\uparrow$ Both the Descriptio and Constructio are reprinted by N. W. L. A. Gravelaar in Verhandelingen der Kon. Akad. van Wet. te Amsterdam, 1 sectie, deel 6, 1899.

$\ddagger$ Mr. Macdonald is also the author of the life of Napier in the Dictionary of National Biography.

$\S$ Somewhat extended analysis of Napier's logarithmic works is given by Delambre in his Histoire de l'Astronomie moderne, tome 1, Paris, 1821, pp. 491-506. See also A. von Braunmühl's Vorlesungen über Geschichte der Trigonometrie, zweiter Teil. Leipzig, 1903. 